\title{
PENGARUH EKSTRAK DAUN PARE (Momordica charantia) TERHADAP FOLIKEL OVARIUM TIKUS (Rattus norvegicus) DALAM KONDISI HYPERGLYCEMIC
}

\section{INFLUENCE OF PARE LEAVES EXTRACT (Momordica charantia) ON FOLICLES OVARY IN RAT (Rattus norvegicus) DUE TO THE EFFECT OF HYPERGLYLEMIC CONDITION}

\author{
Ganeswara Muharam Hazmi Rezady ${ }^{1)}$, Hani Plumeriastuti ${ }^{2}$, Rimayanti $^{3 \text { ) }}$ \\ ${ }^{1)}$ Student, ${ }^{2)}$ Veterinary Pathology Department, ${ }^{3)}$ Veterinary Reproduction Department \\ Faculty of Veterinary Medicine, Airlangga University \\ *Corresponding author: hani-p@ fkh.unair.ac.id; gwara.gw@gmail.com
}

\begin{abstract}
The purpose of this study was to prove that the provision of pare leaf extract can reduce the process of follicular atrophy in the ovaries caused by hyperglycemic conditions. The total of this study was completed within 20 days, including the induction of Streptozotocin for 5 days, treatment for 14 days, and 1 day for ovarian collection. The $\mathrm{K}$ - group as a negative control without being induced by Streptozotocin and received no treatment. The $\mathrm{K}+$ group as a positive control was only induced by Streptozotocin at a dose of $55 \mathrm{mg} / \mathrm{Kg} \mathrm{BW}$ and $\mathrm{D}_{10}$ without treatment. The T1 group was induced by Streptozotocin at doses of $55 \mathrm{mg} / \mathrm{Kg} \mathrm{BW}$ and $\mathrm{D}_{10}$ and treated with pare leaves extract (Momordica charantia) at a dose of $1.26 \mathrm{ml} / \mathrm{Kg}$ BW. T2 group was induced by Streptozotocin with dose of $55 \mathrm{mg} / \mathrm{Kg} \mathrm{BW}$ and $\mathrm{D}_{10}$ and was treated with pare leaves extract (Momordica charantia) at a dose of $2.52 \mathrm{ml} / \mathrm{Kg} \mathrm{BW}$. Induction of Streptozotocin intraperitoneally and once-daily peroral treatment. The result showed that treatment group could make a significant difference with the positive control. Showing that amount of gap could make Momordica charantia to be alternative treatment for hyperglycemic condition.
\end{abstract}

Key word: Hyperglycemic, Follicular Atrophy, Streptozotocin, Momordica charantia.

\section{Introduction}

Diabetes mellitus is a collection of symptoms that arise in a person caused by an increase in blood glucose levels due to decreased insulin secretion progressively backed by insulin resistance (Suyono, 2011). Diabetes mellitus is a chronic, heterogeneous and life-threatening disease that is usually a metabolic disorder.

Hyperglycaemia can be caused by many things, but most often it is by diabetes mellitus. Hyperglycemia is a medical term for circumstances where blood sugar levels are higher than normal. In hyperglycemia, sugar accumulates in the blood because it fails to enter the cell. Failure occurs due to hormones that help the entry of blood sugar into the cell, the insulin hormone. Failure is common because the amount of the hormone is less or defective function. The insulin hormone itself is produced by the pancreas.

In rats (Rattus norvegicus) normal blood glucose level is $62-175 \mathrm{mg} / \mathrm{dl}$ (Malole and Pramono 1999), if the blood glucose level exceeds that number then the mouse can be ascertained in hyperglycemic state. Hyperglycemic can cause metabolism of carbohydrate, protein, and lipid disorders. Metabolic disorders can cause failure in various organs, especially the eyes, kidneys, nerves, heart, and blood vessels (Kurniawan 2005, Lumbantobing 2003), as well as on the reproductive organs.

According to Garris (1994) hyperglycemic conditions in Chinese hamsters (Cricetus griseus) can cause damage to the endometrial structure resulting in widespread epithelial extension in the lumen and degeneration of the stromal membrane, the occurrence of uterine cell atrophy and lipid 
accumulation. Based on research Garris and Garris (2003), in hyperglycemic rats occur atrophy follicle due to the accumulation of lipids. Hyperglycemic conditions in the female reproductive system can affect the function of ovarian follicles. The hyperglycemic state affects glucose transport in the ovary and estrogen production produced by the ovarian follicle so that estrogen levels in the body become low (Cox et al., 1994). In estrogen mice will affect the sensitivity of the vaginal epithelium to be codified as a sign that the mice have entered the estrous stage (Jesionowska et al., 1990). Thus the hyperglycemic state is suspected to affect the ovarian structure and estrus cycle in mice.

Selection of the use of pare (Momordica charantia) as a medicine is obtained from empirical evidence conducted in many countries around East Asia, Japan, Korea, and China. In addition, the Amazon community has traditionally used this plant especially the leaves to treat Diabetes Mellitus disease. In general the part used is a water decoction of the leaf (dekoktum). In the leaves of this plant contains momordisina, momordina, carantina, resin, and oil. Momordica charantia has antimicrobial activity, antioxidants and cytotoxic effects derived from momordisina and momordina. Antioxidants can form cell defense mechanisms against free radical damage (Manna, Sinha and Sil, 2009).

\section{Materials and Methods}

The research conducted in Veterinary Pathology Laboratory of Veterinary Medicine Faculty of Airlangga University Surabaya, for the extraction process of Momordica charantia held in "Balai Penelitian dan Konsultasi Industri - Laboraturium Penelitian dan Konsultasi Industri" Surabaya, and at "Kandang Hewan Coba" Laboratory of Veterinary Medicine Faculty of Airlangga University Surabaya for preparation and staining of ovarian tissue, also at Biochemistry Laboratory of Medical Faculty of Airlangga University Surabaya. The study lasted for 1 month, beginning on August 2017 until September 2017.

After 7 days of adaptation of the room, each mouse was weighed. A total of 20 rats were divided into 4 groups containing 5 mice. The first group becomes a negative control. The second group was a positive control given STZ resulting in a hyperglycemic condition. The third group was given STZ and M. charantia extract by $50 \%$. And lastly the fourth group was given STZ and extract M. charantia at $100 \%$.

Group 2,3,4 injected STZ 55mg / kg BW as much as $0,1 \mathrm{ml}$ on the same day. The rat tail was soaked in warm water for 1-2 minutes to allow vaso dilation, then the needle was inserted parallel to the tail and a $0.1 \mathrm{ml} \mathrm{STZ}$ solution was injected according to $55 \mathrm{mg} / \mathrm{kg} \mathrm{BW}$ through the intraperitonial for 4 consecutive days, up to 4 days ahead of the addition of D10 dissolved with drinking water. 24 hours after the injection, blood sampling through the tail and blood glucose was examined using a glucostix measuring device (glucostix). Rats were maintained in a hyperglycemic state.

On the 13th day the adminwastration of Momordica charantia extract for group 3 with dose $1.26 \mathrm{~g} / \mathrm{kg} \mathrm{BW}$ and for group 4 with dose $2.52 \mathrm{~g} / \mathrm{kg} \mathrm{BW}$. This treatment was carried out for 14 days. On the 28th day the termination was taken and then the ovaries were taken for the preparation of histology preparations.

Preparation of ovarian preparation was done using paraffin method and hematoxylin-eosin staining. The first step was to do ovarian fixation with $10 \%$ PBS formaliform solution, followed by dehydration using stratified alcohol and clearing using xylol. After clearing was done paraffin infiltration and embedding in paraffin. After the paraffin blocks were formed the blocks were attached to the holder, trimming, and slicing using rotary microtom. The formed bands were affixed to affixing. The latter process was staining with hematoxylin-eosin dye. The final step was the mounting (Handari, 1993). Observation of ovarian structure was done by counting the number of primary follicular atresi, secondary atresi, tertiary atresi, and corpus luteum on the incwasion of ovarian histology. 


\section{Result and Discussion}

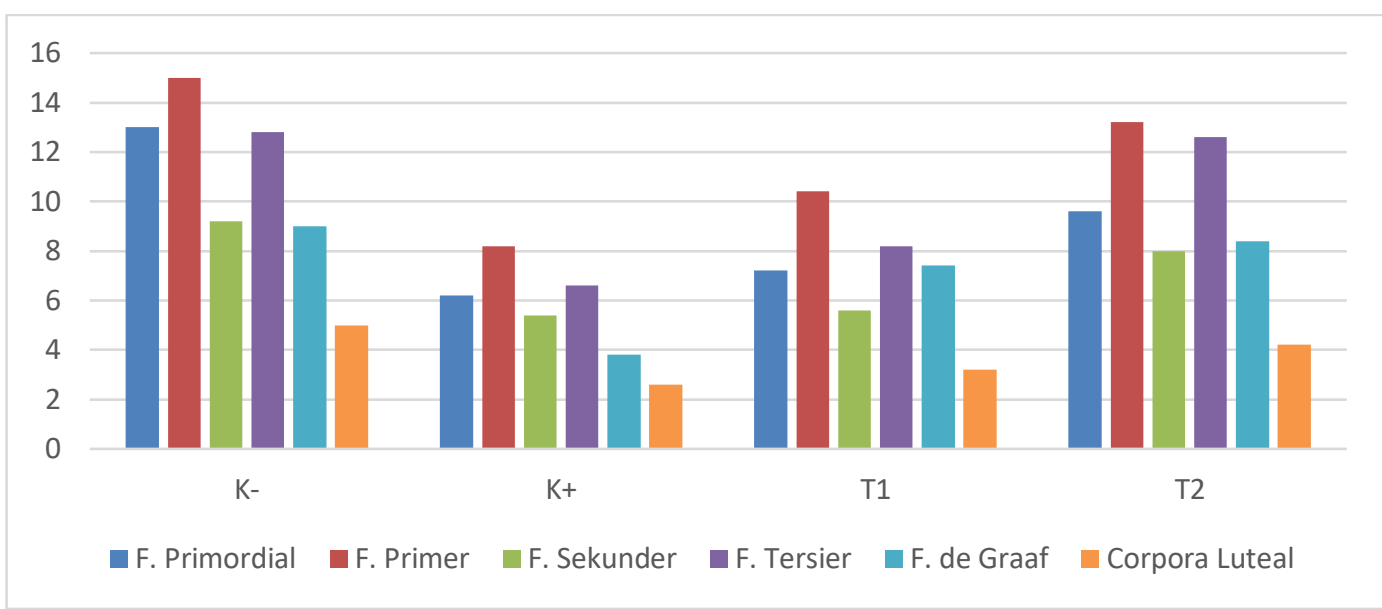

Figure 1. Diagram of average and standard deviation of observation of the number of ovarian follicles

Group K- became a negative control group that was not exposed or treated. For groups of $\mathrm{K}+, \mathrm{T} 1$, and $\mathrm{T} 2$ the experimental animals were induced with Streptozotocin (STZ) at doses of $55 \mathrm{mg} / \mathrm{Kg} \mathrm{BW}$ intraperitoneally and D10 infused by mixing into drinking water, after which the mice got hyperglycemic conditions. For the $\mathrm{K}+$ group after animals try to be induced by Streptozotocin (STZ) at doses of $55 \mathrm{mg} /$ $\mathrm{Kg}$ BW and D10 and became hyperglycemic, animals try didn't get any treatment to make positive control of hyperglycemic conditions. While the $\mathrm{T} 1$ and $\mathrm{T} 2$ groups after induced by Streptozotocin (STZ) with dose of $55 \mathrm{mg} / \mathrm{Kg} \mathrm{BW}$ and D10 and became hyperglycemic, the animals try got the treatment of pare leaf extract (Momordica charantia) with the dose of $1.26 \mathrm{ml} /$ $\mathrm{Kg} \mathrm{BW} \mathrm{(T1)} \mathrm{and} 2.52 \mathrm{ml} / \mathrm{Kg} \mathrm{BW}$ (T2) once a day orally. This treatment was carried out for 2 weeks / 14 days.

Based on figure 1, The results of examination of the number of follicles in white rats after induced Streptozotocin with a dose of $55 \mathrm{mg} / \mathrm{kg} \mathrm{BW}$ and then given therapy with pare leaf extract with a dose of $1.26 \mathrm{ml} / \mathrm{kg}$ BW and $2.52 \mathrm{ml} / \mathrm{Kg} \mathrm{BW}$ showed a significant effect on the reduction of atrophy white rat follicles.

In the experimental group that was not induced by Streptozotocin and did not receive any therapy of pare leaf extract $(\mathrm{K}$ ), showed the mean values of premodial follicles 13 , primary follicles 15 , secondary foolicles 9.2 , tertiary follicles 12.8 , follicles de graaf 9, and corpus luteum 5. This value indicated the average number of follicles in white mice under normal conditions.

In the experimental group of Streptozotocin-only animals with a dose of $55 \mathrm{mg} /$ $\mathrm{kg} \mathrm{BW}$ and D10 without treatment of pare leaf extract $(\mathrm{K}+)$, showed the mean values of premodial follicles 6.2, primary follicles 8.2, 5.4 secondary foolicles, follicles tertiary 6,6 , follicles de graaf 3,8 , and corpora luteal 2,6. From the average results obtained showed significant results when compared with normal conditions (K-).

Streptozotocin is a glucosamine-nitrosourea compound. As with other alkylating agents in the nitrosourea class, it is toxic to cells by causing damage to the DNA, though other mechanisms may also contribute. DNA damage induces activation of poly ADP-ribosylation, which is likely more important for diabetes induction than DNA damage itself (Szkudelski T, 2001). Streptozotocin was similar enough to glucose to be transported into the cell by the glucose transport protein GLUT2, but was not recognized by the other glucose transporters. This explained its relative toxicity to beta cells, since these cells have relatively high levels of GLUT2 (Wang Z, Gleichmann H, 1998). Administration of D10 was performed to increase blood sugar levels after induction of Streptozotocin (STZ).

According to Colton et al. (2003) reduced communication between granulosa cells leads to altered paracrine communi- 
cation between oocytes and granulosa cells. In addition, follicle cell cells required nutrient supply through the gap junction for oocyte development. The gap junction was a special area of adjacent cell membranes that allow for the communication between these cells (Granot and Dekel, 1998). Gap junctions play an important role in the development of granulosa cells, differentiation and luteinization (Kidder and Mahwi 2002 in Krysko et al., 2004). In follicle development, such communication is also needed to control the meiotic state of the oocyte. The types of protein gap junctions were known as connexin. Granulosa cells are known to express connexin-43 while in the oocytes are connexin-37 (Granot and Dekel 1998) Based on a study of Chang et al. (2005), hyperglycaemia caused decreased expression of connexin-43 protein that affected intracellular communication in granulosa cells and increased apoptosis in these granulosa cells. This is similar to that of Colton et al. (2003) suggesting that high glucose levels simultaneously also increased apoptosis in granulosa cells.

In the experimental group that Streptozotocin-induced dose of $55 \mathrm{mg} / \mathrm{Kg} \mathrm{BW}$ and D10 treated with pare leaf extract 1.26 $\mathrm{ml} / \mathrm{Kg} \mathrm{BW}$ (T1) and $2.52 \mathrm{ml} / \mathrm{Kg} \mathrm{BW}$ (T2), showed the mean respectively from the premodial follicles of 7.2 and 9.6, the primary follicles of 10.4 and 13.2, the secondary follicles 5,6 and 8 , the tertiary follicles 8.2 and 12.6, the graft follicles of 7.4 and 8, 4, and corpora luteal 3.2 and 4.2. These results indicated that pare leaf extract could reduce the occurrence of atrophy and decreased the blood glucose levels of Streptozotocin-induced white rats but less significant for the group with a dose of 1.26 $\mathrm{ml} / \mathrm{Kg} \mathrm{BW}$ (T1). The results shown in the group were almost the same as those without treatment $(\mathrm{K}+)$.

In group $\mathrm{T} 2$ the number of follicles in white rats was premodial follicle 9.6, primary follicles 13.2 , secondary foolicles 8 , tertiary follicles 12.6 , follicles de graaf 8.4, and corpora luteal 4.2. This was a result of near normal conditions. In the T2 group using a dose of pare leaves extract of $2.52 \mathrm{ml} / \mathrm{Kg} \mathrm{BW}$ for 14 days, this dose was very effective to reduce the occurrence of atrophy of follicles in white rats that have been induced by Streptozotocin at a dose of
$55 \mathrm{mg} / \mathrm{Kg} \mathrm{BW}$. It also proved that pare leaf extract could be an alternative therapy for diabetes mellitus.

One of the content of pare leaves was flavonoids. Flavonoids have acarbose-like effects that inhibited the enzyme $\alpha$-glucosidase that serves to break down polysaccharide compounds into glucose monomers, so that the absorption of glucose in the intestine is reduced and blood glucose levels decrease (Hartika, 2009).

According Ardra (2017), some phytochemical compounds contained in pare leaves are momordina, momordicina, resinic acid, charantine, tricosanin acid, resin, saponin, vitamin A and D, and fat. Saponins can help reduce blood glucose levels because they can form a membrane layer on the surface of the small intestine, thereby inhibiting glucose absorbs (Mills and Kerry, 2000). Limtrakul et al., (2012) also argues that saponins have a polypeptide structure similar to insulin to act as "insulin like" in lowering blood glucose levels.

\section{Conclussion}

Based on the results of this study could be concluded that the provision of pare leaf extract (Momordica charantia) could reduce blood glucose levels and reduced the atrophy of the white rat's ovarium follicles (Rattus norvegicus) induced Streptozotocin (STZ).

\section{Refferences}

Ardra, 2017. Ekstraksi Flavonoid Dari Daun Pare (Momordica Charantia L.). Institut Pertanian Bogor. Bogor.

Colton, S.A., P.G. Humpherson, H.J. Leese and S.M. Downs. 2003. Physiological Changes in Oocytecumulus Cell Complexes from Diabetic Mice that Potentially Influence Meiotic Regulation. Biology of Reproduction. 69: 761-770.

Cox, N.M., K.A. Meurer, C.A. Carlton, R.C. Tubbs and D.P. Mannis. 1994. Effect of Diabetes Mellitus during the Luteal Phase of Oestrous Cycle on Preovulatory Follicular Function, Ovulation and Gonadotrophins in Gilts. Journal of Reproduction and Fertility. 101:77-86.

Garris, D. R. 1994. Effects of Progressive Hyperglycemia on Ovarian Structure and Function in the Spontaneously 
Diabetic Chinese Hamster. 210(3): 485-489.

Garris, D. R., and B.L. Garris. 2003. Diabetes-induced. Progressive Endometrial Involution Characterization of Periluminal Epithelial Lipoanathrophy. Experimental Biology and Medicine. 52 (1): 51-58.

Granot, I. and N. Dekel. 1998. Cell-to-Cell Communication in The Ovarian Follicle: Development and Hormonal Regulation of The Expression of Connexin 43. Human Reproduction 13 Suppl:4. European Society for Human Reproduction and Embryology.

Handari, S. 1993. Metode Pewarnaan : Histologi \& Histokimia. Bhatara Karya Aksara.

Hartika, 2009. Isolasi Komponen Bioaktif Flavonoid dari Tanaman Daun Dewa (Gynura pseudochina L.). (Tesis). Institut Pertanian Bogor. Bogor.

Jesionowska H. 1990. Determination of Insulin and Insulin-like Growth Factors in the Ovarian Circulation. Fertil Steril. 53: 88-91.

Kidder G.M. and Mahwi A.A. 2002. Gap junctions and ovarian folliculogenesis. Reproduction. 123: 613-620.

Kurniawan, A.A. 2005. Diabetes Mellitus. Prosiding Symposium An Up-date The Management of Diabetes Mellitus. Solo, 19 Maret 2005. Solo: Panitia Pelantikan Dokter Periode 151. Fakultas Kedokteran Universitas Sebelas Maret

Limtrakul, P., P. Pitchakarn, S. Ohnuma, K. Pintha, W. Pompimon, and S.V. Ambudkar. 2012. Kuguacin J isolated from Momordica charantia leaves inhibits Pglycoprotein (ABCB1)- mediated multidrug resistance. J Nutr Biochem. 23: 76-84.

Lumbantobing SM. 2003. Stroke Bencana Peredaran Darah di Otak. Jakarta: Balai penerbit Fakultas Kedokteran Universitas Indonesia.

Malole, M.B.M. and C.S.U Pramono. 1999. Pengantar Hewan-Hewan Percobaan di Laboratorium. Pusat Antara Universitas Bioteknologi IPB. Bogor.

Manna, P., M. Sinha, and P.C. Sil. 2009 a. Protective Role of Arjunolic Acid in Response to Streptozotocin-in-duced thpe-I Diabetes Via the Mitochondrial Dependent and Independent Pathaway. Toxicology. 257: 53-63.

Mills S. and Kerry B. 2000. Principles and Practice of Phytotherapy. United States of America: Churchill Livingstone, p. 394-402.

Suyono, S., 2011. Kecenderungan Peningkatan Jumlah Penyandang Diabetes Melitus dalam: Soegondo, S., Soewondo, P., Subekti, I., Editor. Penatalaksanaan Diabetes Melitus Terpadu bagi dokter maupun educator diabetes. Fakultas Kedokteran Universitas Indonesia. Jakarta.

Szkudelski T. 2001. The mechanism of alloxan and streptozotocin action in B cells of the rat pancreas. Department of Animal Physiology and Biochemistry, University of Agriculture, Poznan, Poland.

Wang, Z. and H. Gleichmann. 1998. GLUT2 in pancreatic islets: crucial target molecule in diabetes induced with multiple low doses of streptozotocin in mice. Clinical Experimental Department, Diabetes Research Institute, Heinrich-Heine University of Düsseldorf, Germany. 